[Radiocarbon, Vol 24, No. 2, 1982, P 182-193]

\title{
GLIWICE RADIOCARBON DATES VIII
}

\author{
MIECZYSEAW F PAZDUR, ROMUALD AWSIUK, \\ ANDRZEJ BLUSZCZ, ANNA PAZDUR, ADAM WALANUS, \\ and ANDRZEJ ZASTAWNY \\ Institute of Physics, Silesian Technical University \\ Krzywoustego 2, PL-44-100 Gliwice, Poland
}

The following list sums up the results of radiocarbon dating of geologic samples obtained mostly during 1978 and 1979. Measurements have continued with the same proportional counters, pretreatment procedures, carbon dioxide purification, measurement and calculation as described previously (Pazdur et al, 1982). Ages are reported as conventional radiocarbon dates in years before AD 1950. No corrections for ${ }^{13} \mathrm{C} /{ }^{12} \mathrm{C}$ ratio were made for samples reported in this date list. Infinite dates are based on a 2-sigma criterion (Pazdur and Walanus, 1979). Sample descriptions and comments are based on information provided by the submitters.

\section{ACKNOWLEDGMENTS}

All samples listed here have been dated with the technical assistance of Helena Skorupka during sample pretreatment and carbon dioxide purification.

\section{SAMPLE DESCRIPTIONS}

GEOLOGIC SAMPLES

\section{A. Poland}

\section{Baltic Coast and N Poland}

\section{Swietousé series}

Charcoal from fossil soil levels covered with eolian sands in cliff undercutting Wolin end moraine, Wolin I. ca $1 \mathrm{~km} \mathrm{~W}$ of Swiętouść $\left(59^{\circ} 30^{\prime} \mathrm{N}, 14^{\circ} 38^{\prime} \mathrm{E}\right)$. Wolin end moraine is built of deposits formed by glacial tectonic processes; upper part of glacial tectonic structures is sheared and covered with fluvial and eolian cover sands with two fossil soil levels. Coll Nov 1978 by R K Borówka and Ryszard Gonera; subm 1979 by R K Borówka, Inst Geog, Adam Mickiewicz Univ, Poznań.

Gd-1062. Swietousé K-35

Sample from younger fossil soil separating 2 series of eolian sands, depth $3.5 \mathrm{~m}$.

\section{Gd-631. Swietousé K-43}

$11.590 \pm 270$

Sample from older fossil soil developed on fluvial (?) sands and covered with eolian sands, depth $7 \mathrm{~m}$. Comment: undersized, diluted.

\section{Troszyn series}

Charcoal and gyttja from fossil soil levels in $\mathrm{N}$ part of parabolic dune near Troszyn, Western Pomerania (53 $\left.52^{\prime} \mathrm{N}, 14^{\circ} 45^{\prime} \mathrm{E}\right)$. Subm 1978 by Stefan Kozarski, Inst Geog, Adam Mickiewicz Univ, Poznań. 
Gd-546. Troszyn 11/BN/77

Charcoal from upper soil level, depth ca $80 \mathrm{~cm}$. Coll Sept 1977 by Bolesław Nowaczyk.

Gd-528. Troszyn 9/BN/76

$2300 \pm 170$

Charcoal from middle soil level, depth 3.75 to $3.85 \mathrm{~m}$. Coll Oct 1976 by Bolesław Nowaczyk.

Gd-529. Troszyn 10/BN/76

$$
\mathbf{3 1 3 0} \pm \mathbf{7 0}
$$

Charcoal from fire layer at top of lower fossil soil, depth 6.40 to $6.46 \mathrm{~m}$. Coll Oct 1976 by Bolesław Nowaczyk.

Gd-538. Troszyn 13/BN/77

$8020 \pm 110$

Coarse-detritus gyttja, thin layer at depth $6 \mathrm{~m}$ underlain by terrace sands and covered with dune sands. Coll Nov 1977 by Andrzej Karczewski and Kazimierz Tobolski. Comment (KT \& BN): expected age: Late Glacial. Contamination with younger rootlets cannot be excluded.

\section{Gd-537. Troszyn 12/BN/77}

$2440 \pm 60$

Charcoal from pit underlying fossil soil in $S$ part of dune, assoc with pottery remains, depth ca $80 \mathrm{~cm}$. Coll Nov 1977 by Tadeusz Wiślański. Comment (TW): assoc cultural material indicates Hallstadt C/D period.

\section{Pomorska Bay R-3 series}

Peaty detritus from lowest part of Core R-3 taken from sea bottom in S part of Pomorska Bay, ca $15.6 \mathrm{~km}$ W of Miedzyzdroje $\left(53^{\circ} 55^{\prime} 55^{\prime \prime} \mathrm{N}\right.$, $\left.14^{\circ} 23^{\prime} 13^{\prime \prime} \mathrm{E}\right)$. Core from sublittoral zone at bottom of a large valley filled up to high level during late stages of Baltic transgression. Now in accumulation zone (Rosa, 1967; Kolp, 1966) at water depth ca 10m. Coll with vibrocorer July 1979 by Radosław Pikies and Zdzisław Sliwiński; subm 1979 by Włodzimierz Kroczka, Geol Inst, Dept Marine Geol, Sopot.

Gd-1143. R3-2220G

$7240 \pm 150$

Top part of peaty slime layer, depth 80 to $87 \mathrm{~cm}$.

Gd-1144. R3-2221G

$7700 \pm 120$

Peaty slime with shells and shell detritus, depth 87 to $107 \mathrm{~cm}$.

Gd-1142. R3-2222G

$8090 \pm 110$

Peaty and shell detritus, depth 107 to $122 \mathrm{~cm}$. Comment (WK): core did not reach base of organic sediments.

\section{Gd-541. Miodowice 1}

$11,190 \pm 180$

Thin layer of peat at depth $2.4 \mathrm{~m}$ underlying alluvial sands near Miodowice village, W Pomerania $\left(53^{\circ} 45^{\prime} \mathrm{N}, 14^{\circ} 42^{\prime} \mathrm{E}\right)$. Coll Oct 1977 and subm by J E Mojski, Geol Inst, Warsaw. Comment (MFP): another portion of sample was dated by Groningen lab: GrN-8890, 10,710 \pm 150 (Mook, written commun, 1979; cf R, 1982, v 24, p 000-000). 
Gd-602. Gac $1 / 78$

Sand with sticky humus from bottom layer in deflation basin, depth 115 to $129 \mathrm{~cm}$, from peat bog in dune area at SE shore of Łebsko Lake, Słowiński Natl Park, $1 \mathrm{~km} \mathrm{NE}$ of Gac village $\left(54^{\circ} 42^{\prime} \mathrm{N}, 17^{\circ} 29^{\prime} \mathrm{E}\right)$. Coll and subm 1978 by Kazimierz Tobolski, Inst Geog, Adam Mickiewicz Univ, Poznan. Dated for studies of dune stratigraphy and paleogeog of Gardno-Keba Lowland (Tobolski, 1972). Comment (KT): younger than expected, pollen analysis indicates pre-Boreal age. Rejuvenation by penetration of younger rootlets is possible.

\section{Sarbsko series}

Peat and wood from two cores taken at shore of Sarbsko Lake near Łeba $\left(54^{\circ} 45^{\prime} 30^{\prime \prime} \mathrm{N}, 17^{\circ} 35^{\prime} 40^{\prime \prime} \mathrm{E}\right)$. Coll 1978 by Boguslaw Rosa; subm by Stanisław Fedorowicz, Dept Geomorphol and Quaternary Geol, Gdańsk Univ, Gdynia.

Gd-1028. Sarbsko 3

Peat from depth 3 to $3.65 \mathrm{~m}$.

$5080 \pm 80$

Gd-592. Sarbsko 4

$15,020 \pm 200$

Fragments of wood in peat layer at depth 9.7 to $11.2 \mathrm{~m}$. Comment (SF): probably driftwood dated; age much older than expected.

\section{Machowinko series}

Peat from layer at depth 2.10 to $3.25 \mathrm{~m}$ in basin without outflow in foreland of frontal moraine surrounding Gardno Lake, $1 \mathrm{~km} \mathrm{~N}$ of Machowinko village $\left(54^{\circ} 37^{\prime} \mathrm{N}, 17^{\circ} 00^{\prime} \mathrm{E}\right), 15 \mathrm{~km} \mathrm{E}$ of Ustka. Coll Dec 1978 by Krzysztof Petelski; subm by Stanisław Fedorowicz.

\section{Gd-1075. Machowinko P.1}

From depth 2.2 to $2.25 \mathrm{~m}$.

$$
8620 \pm 90
$$

\section{Gd-635. Machowinko P.2}

From depth 2.65 to $2.75 \mathrm{~m}$.

$$
8590 \pm 100
$$

\section{Gd-594. Mierzeja Lebska 5/BR}

$1800 \pm 60$

Fragment of decayed tree trunk found in situ on surface of biogenic sediments in beach at Mierzeja Lebska $\left(54^{\circ} 45^{\prime} 45^{\prime \prime} \mathrm{N}, 17^{\circ} 30^{\prime} 00^{\prime \prime} \mathrm{E}\right)$. Coll 1978 by Bogusław Rosa; subm by Stanisław Fedorowicz.

\section{Gd-1066. Gardno 78/KP}

Single layer of peat in vicinity of Gardno Lake $\left(54^{\circ} 39^{\prime} 48^{\prime \prime} \mathrm{N}, 17^{\circ}\right.$ 09' 20" E). Coll 1978 by Krzysztof Petelski, subm by Stanisław Fedorowicz.

\section{Gd-1230. Osieki}

$$
9760 \pm 80
$$

Sandy detritus with wood fragments from layer at depth 1.1 to $1.2 \mathrm{~m}$ on slope of small valley in $\mathrm{N}$ part of Lębork Upland, NNW of Choczewo $\left(54^{\circ} 47^{\prime} \mathrm{N}, 17^{\circ} 51^{\prime} \mathrm{E}\right)$. Coll Nov 1979 and subm by Sylwester Skompski, Geol Inst, Warsaw (Sylwestrzak, 1969). 
Gd-1049. Czymanowo prof a

$10,600 \pm 100$

Peat from layer at bottom of postlacustrine depression overlain by other lacustrine sediments (calcareous gyttja and lacustrine chalk) and peat, from peaty plain at Czymanowo near Choczewo $\left(54^{\circ} 44^{\prime} \mathrm{N}, 18^{\circ} 5^{\prime} \mathrm{E}\right)$. Coll Sept 1978 and subm by Sylwester Skompski. Comment (MFP): alkali-soluble fraction dated.

\section{Hel-Jastarnia series}

Samples from two organic layers in core reaching Tertiary sediments near Jastarnia, Hel peninsula $\left(54^{\circ} 40^{\prime} 35^{\prime \prime} \mathrm{N}, 18^{\circ} 40^{\prime} 30^{\prime \prime} \mathrm{E}\right)$. Coll 1978 by Bogusław Rosa; subm by Stanisław Fedorowicz.

\section{Gd-1027. Hel-Jastarnia 1}

$5370 \pm 100$

Peat from depth 3 to $5 \mathrm{~m}$.

Gd-593. Hel-Jastarnia 2

$>\mathbf{3 8 , 8 0 0}$

Wood fragments from peat layer at depth 59 to $59.8 \mathrm{~m}$. Comment (SF): probably driftwood was dated; age much older than expected.

\section{Gd-539. Lipce 3c}

$9690 \pm 150$

Humic detritus from bottom layer at depth 21 to $23.6 \mathrm{~m}$ underlying Wisła $\mathrm{R}$ deltaic sediments in Lipce village, Zuławy ( $\left.51^{\circ} 54^{\prime} \mathrm{N}, 19^{\circ} 56^{\prime} \mathrm{E}\right)$. Coll and subm 1978 by J E Mojski.

\section{Orunia series}

Layer of humic detritus ca $8 \mathrm{~m}$ thick, in deltaic sediment of Wisła R, loc Orunia, Gdańsk, Zulawy $\left(54^{\circ} 18^{\prime} 00^{\prime \prime} \mathrm{N}, 18^{\circ} 37^{\prime} 30^{\prime \prime} \mathrm{E}\right)$. Coll and subm 1978 by J E Mojski.

Gd-549. Orunia 9b+a, S2

$7300 \pm 110$

From depth 8 to $11.2 \mathrm{~m}$.

Gd-540. Orunia 9b+a, S1

$5420 \pm 110$

From depth 5 to $8 \mathrm{~m}$.

\section{Wisłoujscie series}

Peat with plant detritus and fragments of wood and twigs with admixture of amber in two layers separated by and underlying finegrained sands in Gdańsk, loc Wisłoujście ( $54^{\circ} 24^{\prime} \mathrm{N}, 18^{\circ} 40^{\prime} \mathrm{E}$ ). Coll Sept 1978 by Stefan Kozłowski and subm by J E Mojski.

Gd-1042. Wisłoujscie 1

$2380 \pm 60$

Single pieces of plant detritus and small twigs coll with tweezers. Upper peat layer at depth 7 to $7.1 \mathrm{~m}$.

Gd-638. Wisłoujscie $1,7-7.1 \mathrm{~m}, \mathrm{~A}$

$3560 \pm 70$

Same layer, fine plant detritus obtained after careful removal of amber grains.

Gd-608. Wisłoujscie

$$
6440 \pm 90
$$

Fragments of wood and twigs from lower peat layer at depth 9 to $9.3 \mathrm{~m}$ overlying black clay with shell fragments and amber. 
Gd-639. Wisłoujscie 1, 9.9.3m, A $\quad 3860 \pm 80$

Same layer, fine plant detritus.

General Comment (MFP): both samples were heterogeneous, composed of some in situ peat with twigs of probably same age, pieces of wood washed in by storm waves, and amber of Tertiary age. Since rejuvenation by rootlets penetration or younger humus, leaching seems improbable. Younger dates of both organic horizons should be considered better approx to real age of formation.

\section{Great Poland Lowland and $W$ Poland}

Gd-611. Laskowo 1/78/BN

$11,380 \pm 170$

Charcoal from fossil humus level at depth $1.45 \mathrm{~m}$ overlying terrace sands of first terrace of Warsaw-Berlin Pradolina and underlying sands of alluvial cone developed in mouth of erosion - denudational valley, $750 \mathrm{~m} \mathrm{E}$ of Laskowo, $8 \mathrm{~km}$ of Sulechów, Great Poland Lowland $\left(52^{\circ} 04^{\prime}\right.$ N, $15^{\circ} 32^{\prime} \mathrm{E}$ ). Coll Aug 1978 and subm by Bolesław Nowaczyk.

\section{Zbrudzewo series}

Organic sediments from peaty paleomeander of older generation filled with biogenic-mineral sediments. Recently used as meadow at SW margin of Zbrudzewo $\left(52^{\circ} 07^{\prime} \mathrm{N}, 17^{\circ} 02^{\prime} \mathrm{E}\right)$ Warta $\mathrm{R}$ valley, $3 \mathrm{~km} \mathrm{~N}$ of Srem. Dated for studies in IGCP 158A Project. Coll July 1978 by Stefan Kozarski and Kazimierz Tobolski; subm by Stefan Kozarski (Kozarski and Rotnicki, 1977).

Gd-1020. Zbrudzewo $\mathrm{Zb} / \mathrm{I} / \mathbf{7 8}$

Black detritus gyttja, top part of gyttja layer at contact with low peat, depth 235 to $241 \mathrm{~cm}$.

Gd-1016. Zhrudzewo $\mathbf{Z b} / \mathbf{I} / 78$

$23,700 \pm 370$

Brown sandy organic mud laminated with fine-grained sand, bottom part of biogenic sediments, depth 350 to $357 \mathrm{~cm}$.

Gd-1022. Zbrudzewo Zb/II/78

$20,270 \pm 200$

Black detritus gyttja from top part of gyttja layer at contact with overlying low peat, depth 170 to $175 \mathrm{~cm}$.

Gd-1021. Zbrudzewo Zb/II/78

$27,500 \pm 1000$

Black detritus gyttja with laminae of mud, bottom part of biogenic sediments, depth 350 to $356 \mathrm{~cm}$.

Gd-1083. Zbrudzewo Zh/I/78A

$1670 \pm 60$

Carex peat, marked change in local phytocenosis, depth 55 to $61 \mathrm{~cm}$.

Gd-651. Zbrudzewo $\mathbf{Z b} / \mathbf{I} / \mathbf{7 8 A}$

$8870 \pm 120$

Carex peat, marked change in local phytocenosis, depth 119 to $125 \mathrm{~cm}$.

Gd-656. Zbrudzewo $\mathbf{Z b} / \mathbf{I} / \mathbf{7 8 A}$

$9400 \pm 100$

Carex peat, marked change in local phytocenosis, depth 175 to $180 \mathrm{~cm}$. 
Gd-1084. Zbrudzewo Zb/I/78A

$14,690 \pm 150$

Carex peat, marked change in local phytocenosis, depth 190 to $195 \mathrm{~cm}$.

\section{Czmoniec series}

Organic sediments from peaty paleomeander of older generation, Warta $\mathrm{R}$ valley near Czmoniec, ca $10 \mathrm{~km} \mathrm{~N}$ of Srem, Great Poland Lowland $\left(52^{\circ} 11^{\prime} \mathrm{N}, 17^{\circ} 00^{\prime} \mathrm{E}\right)$. Coll July 1978 by Stefan Kozarski and Kazimierz Tobolski and subm by Stefan Kozarski. Dated for studies in IGCP 158A Project.

Gd-585. Czmoniec $\mathrm{Cz} / \mathrm{I} / \mathbf{7 8}$

$4130 \pm 70$

Sand with laminae of detritus gyttja and allochthonous wood, boundary between sands and underlying gyttja, 219 to $225 \mathrm{~cm}$ below surface of peaty paleomeander.

Gd-584. Czmoniec $\mathrm{Cz} / \mathrm{I} / \mathbf{7 8}$

$4130 \pm 80$

Detritus gyttja with admixture of sand from bottom of organic sediments, 250 to $256 \mathrm{~cm}$ below surface of peaty paleomeander.

Gd-589. Czmoniec $\mathrm{Cz} / \mathrm{II} / 78$

$1960 \pm 70$

Brown-gray organic mud from bottcm part of organic sediments, depth 415 to $420 \mathrm{~cm}$.

Gd-588. Czmoniec $\mathrm{Cz} / \mathrm{II} / \mathbf{7 8}$

$2380 \pm 70$

Gray detritus gyttja with rich admixture of sand, bottom part of organic sediments, depth 445 to $450 \mathrm{~cm}$.

\section{Jaszkowo series}

Carex peat with charcoal layers from upper peat layer in peaty paleomeander, flood plain of Warta $\mathrm{R}$ valley near Jaszkowo $\left(52^{\circ} 10^{\prime} \mathrm{N}\right.$, $16^{\circ} 57^{\prime} \mathrm{E}$ ) ca $9 \mathrm{~km} \mathrm{~N}$ of Srem, Great Poland Lowland. Coll 1977 by Kazimierz Tobolski; subm 1978 by Stefan Kozarski. Dated for studies in IGCP 158A Project of stratigraphy of floodplain deposits and changes of Warta R channel during Late Würn and Holocene (Kozarski and Rotnicki, 1977).

Gd-1079. Jaszkowo Ja/77A

$6210 \pm 80$

Depth 75 to $80 \mathrm{~cm}$.

Gd-1081. Jaszkowo Ja/77A

$7790 \pm 80$

Depth 115 to $120 \mathrm{~cm}$.

Gd-1082. Jaszkowo Ja/77A

$8500 \pm 100$

Depth 185 to $190 \mathrm{~cm}$. Comment (MFP): for other dates from this locality, see Kozarski and Rotnicki (1977) and R, 1978, v 20, p 409; R, 1979, v 21, p 166-167.

\section{Bóbr River series}

Wood, fragments of largest tree trunks, found during exploitation of sands and gravels in gravel pits in Bóbr R valley. Subm 1978 by 
Teofil Dzioba and Ireneusz Wróbel, Polish Fellows Soc Earth Sci, Zielona Góra. For more general outline, see Dzioba (1978).

Gd-513. Nowogród Bobrzański 1/77

$1230 \pm 60$

Oak wood from trunk, $10.5 \mathrm{~m}$ long and $1.2 \mathrm{~m}$ diam, lying horizontally at depth $7 \mathrm{~m}$ in accumulation terrace of Bóbr $\mathrm{R}$ near Nowogród Bobrzański $\left(51^{\circ} 49^{\prime} 18^{\prime \prime} \mathrm{N}, 15^{\circ} 13^{\prime} 54^{\prime \prime} \mathrm{E}\right)$. Coll Nov 1977 by Henryk Łysik.

Gd-514. Olszna 2/77A

$1750 \pm 70$

Oak wood from trunk found in accumulation terrace of Bóbr $\mathrm{R}$ near Olszna (51 $\left.25^{\prime} 24^{\prime \prime} \mathrm{N}, 15^{\circ} 36^{\prime} 30^{\prime \prime} \mathrm{E}\right)$. Coll Oct 1977 by Henryk Łysik.

Gd-515. Olszna 2/77B

$1700 \pm 80$

Duplicate run on second part of same sample.

Gd-517. Gryzyce 4/77

$3670 \pm 80$

Oak wood from tree trunk, $12.5 \mathrm{~m}$ long and $0.9 \mathrm{~m}$ diam, found in series of sandy gravels, accumulation terrace of Bóbr $\mathbf{R}$ near Gryzyce ( $51^{\circ} 38^{\prime} 24^{\prime \prime} \mathrm{N}, 15^{\circ} 17^{\prime} 24^{\prime \prime}$ E). Coll Oct 1977 by Henryk Łysik.

Gd-516. Dobruszów 3/77

$4120 \pm 130$

Oak wood from trunk, $14.5 \mathrm{~m}$ long and $0.8 \mathrm{~m}$ diam, found at depth $7 \mathrm{~m}$ in sandy gravel sediments of accumulation terrace of Bóbr $\mathrm{R}$ near

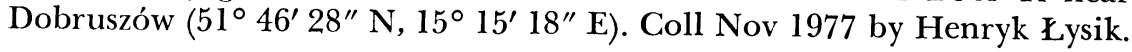

Gd-1040. Dobruszów 5/78

$950 \pm 50$

Pine wood from trunk, ca $12 \mathrm{~m}$ long and $0.6 \mathrm{~m}$ diam, found at depth ca $3 \mathrm{~m}$ in sandy gravels, accumulation terrace of Bóbr $\mathrm{R}$ near Dobruszów (51 $46^{\prime} 29^{\prime \prime} \mathrm{N}, 15^{\circ} 15^{\prime} 18^{\prime \prime}$ E). Coll April 1978 by Teofil Dzioba.

Gd-606. Jedrzychowice $n / Z g o r z e l e c$

$6380 \pm 90$

Oak wood from tree trunk, $0.6 \mathrm{~m}$ diam, found at depth ca $3 \mathrm{~m}$ in sandy gravel sediments of Nysa Luzycka R near Jedrzychowice $\left(51^{\circ} 10^{\prime}\right.$ $\left.51^{\prime \prime} \mathrm{N}, 15^{\circ} 1^{\prime} 38^{\prime \prime} \mathrm{E}\right)$. Coll March 1978 by Jerzy Baczyński.

\section{Kujawy and Mazowiecka Plain}

\section{Torun-Nieszawka series}

Peat, small fossil layer in substratum of flood plain of Wisła $\mathrm{R}$ valley, Toruń-Bydgoszcz basin, left bank of Wisła $\mathrm{R}$ between Toruń and Mała Nieszawka, inside flood rampart $\left(53^{\circ} 00^{\prime} 00^{\prime \prime} \mathrm{N}, 18^{\circ} 35^{\prime} 30^{\prime \prime} \mathrm{E}\right)$. Peat layer overlies fine sands and underlies packing of sandy-gravelly sediments, $40 \mathrm{~cm}$ thick, with cobbles and alluvial series of fine sands and silts, $3.6 \mathrm{~m}$ thick. For general inf on geomorphology of area, see Tomczak (1965) and Niewiarowski and Tomczak (1969). Coll Nov 1978 by Anna Tomczak and Bozena Noryśkiewicz; subm 1979 by Anna Tomczak, Inst Geog, Mikołaj Kopernik Univ, Torun.

Gd-1065. Toruń-Nieszawka 5A

From top of peat layer, depth $4 \mathrm{~m}$. 
Gd-633. Toruń-Nieszawka 5B

From bottom of peat layer, depth $5.1 \mathrm{~m}$.

\section{Toruń-Pedzewo series}

Peat from organic layer in substratum of flood plain of Wisła $\mathbf{R}$ valley, Toruń-Bydgoszcz Basin, ca $15 \mathrm{~km} \mathrm{~W}$ of Torun, right bank of Wisła $\mathrm{R}$ near Pędzewo $\left(53^{\circ} 05^{\prime} 00^{\prime \prime} \mathrm{N}, 18^{\circ} 21^{\prime} 30^{\prime \prime} \mathrm{E}\right)$. Peat layer overlies sandy mud and underlies fine- and medium-grained sands with laminae of sandy mud. Coll Nov 1978 by Bozena Noryśkiewicz and Anna Tomczak and subm 1979 by Anna Tomczak.

Gd-627. Toruń-Pedzewo A

$1930 \pm 70$

From top of peat layer, depth $0.5 \mathrm{~m}$. Comment (AT): contamination by contemporary rootlets possible; date fits limits of expected age fairly well.

\section{Gd-630. Toruń-Pedzewo B}

From bottom of peat layer, depth $1.7 \mathrm{~m}$. Comment (AT): pollen analysis of bottom part of peat layer made by Bozena Noryśkiewicz indicates Atlantic or younger age.

\section{Zgłowiaczka R series}

Samples from valley of Zgłowiączka $R$, Kujawy region, dated to establish chronology of river channel formation during Late Glacial and Holocene in relation to development of Wisła R valley. Coll 1979 and subm by Leon Andrzejewski, Inst Geog and Spatial Org, Polish Acad Sci, Torun.

\section{Gd-1149. Wieniec WI}

Peat from bottom part of floodplain sediments, 2.5 to $3.5 \mathrm{~m}$ thick, composed of peats with inserted layers of muds or fine silty sands. Coll from depth 2.8 to $2.95 \mathrm{~m}$, ca $10 \mathrm{~km} \mathrm{~W}$ of Włocławek, $1 \mathrm{~km} \mathrm{~W}$ of Wieniec village $\left(52^{\circ} 39^{\prime} \mathrm{N}, 18^{\circ} 54^{\prime} \mathrm{E}\right)$.

\section{Gd-1153. Wieniec WII}

Peat from bottom part of fossil meander, depth 1.85 to $2 \mathrm{~m}$, ca $2 \mathrm{~km}$ $\mathrm{E}$ of Wieniec village $\left(52^{\circ} 40^{\prime} \mathrm{N}, 18^{\circ} 58^{\prime} \mathrm{E}\right)$.

Gd-1156. Wieniec WIII

$10,160 \pm 180$

Dusty gyttja with fragments of partly decomposed plants from bottom part of old meander, depth 2.3 to $2.45 \mathrm{~m}$, ca $2.5 \mathrm{~km}$ E of Wieniec village $\left(52^{\circ} 40^{\prime} \mathrm{N}, 18^{\circ} 58^{\prime} \mathrm{E}\right)$.

\section{Gd-1155. Kazanie KI}

$$
9250 \pm 140
$$

Sandy detritus with organic matter from bottom part of glacial trough, depth 7.5 to $7.7 \mathrm{~m}, 600 \mathrm{~m} \mathrm{~S}$ of Kazanie village $\left(52^{\circ} 33^{\prime} 30^{\prime \prime} \mathrm{N}, 18^{\circ}\right.$ $\left.54^{\prime} \mathrm{E}\right)$.

Gd-1147. Kazanie KII

$$
6620 \pm 70
$$

Peat from same profile, depth 5.4 to $5.5 \mathrm{~m}$. 


\section{Raciazek series}

Dispersed fragments of charcoal and amorphic humus coal in loess layer below fossil soil in Raciązek, Kujawy region $\left(52^{\circ} 51^{\circ} 30^{\prime \prime} \mathrm{N}, 18^{\circ}\right.$ $49^{\prime} 30^{\prime \prime} \mathrm{E}$ ). Coll March 1979 and subm by MD Baraniecka, Geol Inst, Warsaw.

Gd-672. Raciazek

From depth 2.5 to $2.6 \mathrm{~m}$. Comment: undersized, diluted.

Gd-792. Raciazek

$11,130 \pm 230$

From depth 3 to $3.1 \mathrm{~m}$. Comment (MDB): loess layer corresponds to Poznanian stage of Vistulian Glaciation, according to Łyczewska (1973).

\section{Gd-1073. Skorupy}

Sandy peat from peat layer covered with fluvial and eolian sands of parabolic dune ca $1 \mathrm{~km}$ SW of Skorupy village near Celestynów $\left(52^{\circ} 03^{\prime}\right.$ $\mathrm{N}, 21^{\circ} 25^{\prime} \mathrm{E}$ ), profile Skorupy 2, depth 6.89 to $6.91 \mathrm{~m}$. Coll and subm 1979 by M D Baraniecka.

General Comment (MDB): pollen analysis by Zofia Janczyk-Kopikowa (written commun, 1978) indicates cold period from end of Brorup interstadial or younger. Fluvial sediments overlying peat layer are of Late Vistulian age. Other radiocarbon dates for this profile measured in Archaeol and Etnogr Mus, Łodź: Lod-25, depth 6.9 to $7 \mathrm{~m},>28,000$; Lod-26, depth 7 to $7.15 \mathrm{~m},>28,000$ (Kanwiszer, written commun, 1978; Konecka-Betley and Baraniecka, 1978).

\section{Fiaski series}

Peat and peaty detritus from Profile 1 in Piaski (51 $\left.11^{\circ} \mathrm{N}, 19^{\circ} 23^{\prime} \mathrm{E}\right)$ near Bełchatów, former flood plain of Widawka R. Quaternary sediments in area of Bełchatów brown-coal open-cast mine were studied by Jurkiewiczowa (1961), Janczyk-Kopikowa (1971), Baraniecka (1971), Baraniecka and Sarnacka (1971) and Rzechowski (1971). Lacustrine deposits in central part of presently studied sec of exposure are described by Baraniecka (1978) and Baraniecka and Pazdur (1979). Coll Oct 1977 and subm 1978 and 1979 by M D Baraniecka.

Gd-1072. Piaski, prof 1/061077, sl

Gd-777. Piaski, prof 1/061077, s2 $-2400$ Peaty detritus, depth ca $12.2 \mathrm{~m}$.

\section{Lesznowola 2 series}

Organic deposits from profile Lesznowola 2, Core 9, near Lesznowola village $\left(51^{\circ} 54^{\prime} 45^{\prime \prime} \mathrm{N}, 20^{\circ} 54^{\prime} 20^{\prime \prime} \mathrm{E}\right)$ Polish Lowland, 6km NE of Grójec, flood plain of Jeziorka R. Core taken in 1976; samples for dating coll and subm 1977 and 1978 by M D Baraniecka. 
Gd-527. Lesznowola 2/I

Fossil soil, depth 7.15 to $7.3 \mathrm{~m}$.

Gd-551. Lesznowola 2/III

Brown organic detritus, depth 7.9 to $8 \mathrm{~m}$.

Gd-552. Lesznowola 2/IV

Sandy mud with organic layer, depth 8.8 to $9.0 \mathrm{~m}$.

Gd-518. Lesznowola 2/II, sol

Peat, depth 10.3 to $10.4 \mathrm{~m}$, alkali-soluble fraction.

Gd-519. Lesznowola 2/II, res

$-2300$

$22,800 \pm 470$

$\mathbf{2 7 , 4 0 0}$

$+2300$

Same sample as Gd-518, insoluble organic residue.

\section{Zoliborz series}

Organic sediments consisting of fossil soil covered by peat and overlain by fine- and medium-grained sands and artificial embankment, near fossil lake, Zoliborz, Warsaw (52 $\left.16^{\prime} \mathrm{N}, 20^{\circ} 56^{\prime} \mathrm{E}\right)$. Coll 1976 and subm 1977 by M D Baraniecka.

Gd-526. Zoliborz Ia

$460 \pm 60$

Peat, depth 2.2 to $2.28 \mathrm{~m}$.

Gd-524. Zoliborz II, sol

$1560 \pm 60$

Fossil soil from depth 2.28 to 2.38 , alkali-soluble fraction.

Gd-525. Zoliborz II, res

$$
1560 \pm 60
$$

Same sample, insoluble residue dated.

$S$ Poland

Gd-1041. Debno

$1880 \pm 50$

Wood, mostly twigs (Alnus incana (?)) id. by Andrzej Obidowicz, from bottom of old channel of Dunajec $R$ in series of silty, sandy deposits at depth $1.15 \mathrm{~m}$, near present mouth of Białka R, alt ca $530 \mathrm{~m}$ asl, $\mathrm{S}$ of Decbno village $\left(49^{\circ} 28^{\prime} \mathrm{N}, 20^{\circ} 13^{\prime} \mathrm{E}\right)$, Podhale. Coll Aug 1975 by Maria Baumgart-Kotarba and Ewa Niedziałkowska, Inst Geog, Dept Geomorphol and Hydrol Mts and Uplands, Polish Acad Sci, Kraków; subm 1978 by MBK. Comment (MBK): younger than expected.

Gd-659. Brzeczowice 10

$1060 \pm 70$

Wood, fragments of trunks of alder and maple at depth ca $5.2 \mathrm{~m}$, overlain by organic slime, sandy dust, dusty till, and artificial embankment, near Brzecczowice, Jasiołka R valley $\left(49^{\circ} 44^{\prime} \mathrm{N}, 21^{\circ} 33^{\prime} \mathrm{E}\right)$. Coll and subm 1978 by Antoni Wójcik, Geol Inst, Carpathian Branch, Cracow. Comment (AW): much younger than expected. 
Gd-605. Kraków-Dabie

Fragment of oak trunk (probably Quercus robur) $0.9 \mathrm{~m}$ diam, exposed at courtyard of Inst Bot, Polish Acad Sci, Cracow. Sample found in 1913 in Wisła $R$ at Dąbie near mouth of Prądnik R (Srodoń, 1980). Subm 1978 by Andrzej Srodon, Inst Bot, Polish Acad Sci, Cracow.

Gd-610. Zemborzyce 1974:150

$10,040 \pm 120$

Valley peat from lower part of Holocene peat cover, depth 3.92 to $3.94 \mathrm{~m}$, flood plain of Bystrzyca $\mathrm{R}$ valley, Lublin, Zemborzyce $\left(51^{\circ} 11^{\prime} 12^{\prime \prime}\right.$ N, $22^{\circ} 32^{\prime} 34^{\prime \prime}$ E). Coll March 1974 and subm 1978 by Henryk Maruszczak, Inst Earth Sci, Maria Curie Skłodowska Univ, Lublin. Comment (HM): pollen analysis by Krystyna Bałaga indicates boundary between Pleistocene and Holocene.

\section{Jarosław (1972:4C:d4:10.33-10.40) series}

Organic loam and peat in form of irregular lenses in fossil bog soil horizon, outcrop in Jarosław, depth 10.33 to $10.4 \mathrm{~m},\left(50^{\circ} 01^{\prime} 13^{\prime \prime} \mathrm{N}, 22^{\circ}\right.$ $38^{\prime} 50^{\prime \prime} \mathrm{E}$ ). Transitional zone between upper terrace of San $\mathrm{R}$ and slope of Carpathian Foreland, younger loess deposits with interstadial soil (Maruszczak, 1976; 1980). Coll Oct 1972 and subm 1978 by Henryk Maruszczak.

Gd-607. Jarosław: acid-sol

Acid-soluble fraction. Comment: undersized, diluted.

Gd-1052. Jarosław : alkali-sol

$21,700 \pm 250$

Alkali-soluble fraction, acid-precipitated part of $\mathrm{NaOH}$-soluble fraction of same sample.

Gd-615. Jarosław : res

Organic residue, insoluble during acid and alkali treatment.

General Comment (HM): pollen analysis by Zofia Janczyk-Kopikowa (written commun, 1974) indicates cold climate Boreal flora with Selaginella spores. For detailed geol profile, of Maruszczak (1976, p 146, fig 2). Bone remains from same level subm for dating by fluorine-apatite-collagen method to Wysoczański-Minkowicz.

\section{Mongolia series}

\section{B. USSR}

Charcoal from fire layers in deposits of small fossil lake, Mongolia, $\mathrm{N}$ Gobi Desert, E slope of Chojra rift valley $\left(45^{\circ} \mathrm{N}, 108^{\circ} \mathrm{E}\right)$. Site is on parapediment developed on granite massive, Iche Narate, ca $1160 \mathrm{~m}$ asl, covered with two series of mud-flow deposits separated by fossil-lake deposits with four fire layers. Coll July 1977 by R K Borówka and Karol Rotnicki; subm 1978 by Karol Rotnicki, Inst Geog, Adam Mickiewicz Univ, Poznań.

Gd-556. Mongolia 176/77

$>44,200$

From upper fire layer, depth ca $1.5 \mathrm{~m}$. 
Gd-557. Mongolia 174/77

From lowest fire layer, depth ca $2.4 \mathrm{~m}$.

\section{REFERENCFS}

Baraniecka, M D, 1971, Dorzecze Widawki na tle obszaru marginalnego stadiału mazowiecko-podlaskiego (Warty) w Polsce: Inst Geol Biul, v 254, p 11-36.

1978, Osady czwartorzędowe w wykopie kopalni węgla brunatnego Bełchatów: Kwart Geol, v 22, p 163-169.

Baraniecka, M D and Pazdur, M F, 1979, Dotowanie metoda C-14 wieku bezwzględnego osadów jeziorno-bagiennych z odsłoniçcia kop. Beł́chatów: Przegl Geol, v 28, p 416.

Baraniecka, M D and Sarnacka, Z, 1971, Stratygrafia czwartorzędu i paleogeografia dorzecza Widawki: Inst Geol Biul, v 254, p 157-270.

Dzioba, Teofil, 1978, Wazniejsze problemy zwiazane $z$ badaniem i wykorzystaniem czarnych debów kopalnychna Ziemi Lubuskiej: PTPNoZ, Sesja Naukowa, Materiały, Oddział Ziemi Lubuskiej, p 139-160.

Janczyk-Kopikowa, Zofia, 1971, Analiza pyłkowa nowych stanowisk interglacjał̀u cemskiego w dorzeczu Widawki: Inst Geol Biul, v 254, p 65-88.

Jurkiewiczowa, I, 1952, Interglacjał Szezercowa i Dzbanck Kościuszkowski w świe:le nowych danych geologicznych: Państw Inst Geol Biul, v 67, p 183-218.

Karczewski, Andrzej and Nowaczyk, Bolesław, 1978, Budowa geologiczna wydmy w Troszynie koło Wolina: Pozn Tow Przyj Nauk, Sprawozdania, No. 94, p 38-40.

Konecka-Betley, Krystyna and Baraniecka, M D, 1978, Charakterystyka gleb kopalnych i reløktowych wytworzonych ze skał róznego pochodzenia geologicznego: Komitet Badań Czwartorzędu PAN, Sprawozdania, No. 2, p 33-38.

Kolp, Otto, 1966, Rezente Fazies der westlichen und südlichen Ostsee: Peterm Geog, Mitt, v 110, No. 1 .

Kozarski, Stefan and Rotnicki, Karol, 1977, Valley floors and changes of river channel patterns in the North Polish Plain during the Late-Würm and Holocene: Quaestiones Geog, v 4, p 51-93.

Łyczewska, J, 1973, Szczegółowa Mapa Geologiczna Polski 1:50 000, ark. Ciechocinek; Inst Geol, Warszawa.

Maruszczak, Henryk, 1976, Stratygrafia lessów Polski południowo-wschodniej: Inst Geol Biul, v 297, p 135-175. 1980, Stratigraphy and chronology of the Vistulian loess in Poland: Quaternary Studies in Poland, v 2, p 57-76.

Niewiarowski, Włodzimierz and Tomczak, Anna, 1969, Morfologia rozwój rzezby obszaru miasta Torunia i jego okolic: Uniw Mikołaja Kopernika, Zeszyty Nauk, Geodg, v 6.

Pazdur, Anna, Awsiuk, Romuald, Bluszcz Andrzej, Pazdur, M F, Walanus, Adam, and Zastawny, Andrzej, 1982, Gliwice radiocarbon dates VII: Radiocarbon, v 24, p 000-000.

Pazdur, M F and Walanus, Adam, 1979, Statistical analysis of data and age calculation in Gliwice Radiocarbon Laboratory: Muz Archeol Etnogr w Lodzi, Prace i Materiały, Ser Archeol, v 26, p 283-289.

Rosa, Bogusław, 1967, Analiza morfologiczna dna poł́udniowego Bałłtyku: Uniw Mikołaja Kopernika, Toruń.

Rzechowski, Jan, 1971, Granulometryczno-petrograficzne własności glin zwałowych w dorzeczu srodkowej Widawki: Inst Geol Biul, v 254, p 111-150.

Sylwestrzak, J, 1969, Odpływ wód roztopowych na tle recesji ladolodu we wschodniej części równiny słupskiej i Wybrzeza Słowińskiego: WSP Gdańsk, Zeszyty Geog, No. czesci.

Srodoń, Andrzej, 1980, Czarny dab z Dabia: Wszechświat, No. 3, p 74.

Tobolski, Kazimierz, 1972, Wiek i geneza wydm przy południowo-wschodnim brzegu jeziora Lebsko: Badania Fizjog nad Polska Zach, ser B, v 25, p 135-146.

Tomczak, Anna, 1965, Mapa Geomorfologiczna Polski 1:50 000, ark Torun: Warszawa, Inst Geog, PAN. 